\title{
The human glucagon-like peptide-1 analogue liraglutide preserves pancreatic beta cells via regulation of cell kinetics and suppression of oxidative and endoplasmic reticulum stress in a mouse model of diabetes
}

\author{
M. Shimoda $\cdot$ Y. Kanda $\cdot$ S. Hamamoto • \\ K. Tawaramoto $\cdot$ M. Hashiramoto $\cdot$ M. Matsuki • \\ K. Kaku
}

Received: 13 September 2010 / Accepted: 22 December 2010/Published online: 22 February 2011

(C) The Author(s) 2011. This article is published with open access at Springerlink.com

\begin{abstract}
Aims/hypothesis We investigated the molecular mechanism by which the human glucagon-like peptide-1 analogue liraglutide preserves pancreatic beta cells in diabetic $d b / d b$ mice.

Methods Male $d b / d b$ and $\mathrm{m} / \mathrm{m}$ mice aged 10 weeks received liraglutide or vehicle for 2 days or 2 weeks. In addition to morphological and biochemical analysis of pancreatic islets, gene expression profiles in the islet core area were investigated by laser capture microdissection and real-time RT-PCR.

Results Liraglutide treatment for 2 weeks improved metabolic variables and insulin sensitivity in $d b / d b$ mice. Liraglutide also increased glucose-stimulated insulin secretion (GSIS) and islet insulin content in both mouse strains and reduced triacylglycerol content in $d b / d b$ mice. Expression of genes involved in cell differentiation and proliferation in both mouse strains was regulated by liraglutide, which, in $d b / d b$ mice, downregulated genes involved in pro-apoptosis, endoplasmic reticulum (ER) stress and lipid synthesis, and upregulated genes related to anti-apoptosis and anti-oxidative stress. In the 2 day experiment, liraglutide slightly improved metabolic variables in $d b / d b$ mice, but GSIS, insulin and triacylglycerol content were not affected. In $d b / d b$ mice, liraglutide increased gene expression associated with cell differentiation, proliferation and
\end{abstract}

M. Shimoda $\cdot$ Y. Kanda $\cdot$ S. Hamamoto $\cdot$ K. Tawaramoto

M. Hashiramoto $\cdot$ M. Matsuki $\cdot$ K. Kaku $(\bowtie)$

Division of Diabetes, Endocrinology and Metabolism,

Department of Internal Medicine, Kawasaki Medical School,

577 Matsushima, Kurashiki,

Okayama 701-0192, Japan

e-mail:kka@med.kawasaki-m.ac.jp anti-apoptosis, and suppressed gene expression involved in pro-apoptosis; it had no effect on genes related to oxidative stress or ER stress. Morphometric results for cell proliferation, cell apoptosis and oxidative stress in $d b / d b$ mice islets were consistent with the results of the gene expression analysis.

Conclusions/interpretation Liraglutide increases beta cell mass not only by directly regulating cell kinetics, but also by suppressing oxidative and ER stress, secondary to amelioration of glucolipotoxicity.

Keywords Apoptosis · Beta cell mass · Cellular differentiation - Cellular proliferation - ER stress .

Glucagon-like peptide-1 - Oxidative stress

\begin{tabular}{|c|c|}
\hline \multicolumn{2}{|c|}{ Abbreviations } \\
\hline $\operatorname{eIF} 2 \alpha$ & Eukaryotic translation initiation factor $2 \alpha$ \\
\hline ER & Endoplasmic reticulum \\
\hline ERK & Extracellular signal-regulated kinase \\
\hline GLP-1 & Glucagon-like peptide-1 \\
\hline GSIS & Glucose-stimulated insulin secretion \\
\hline HES1 & Hairy and enhancer of split-1 \\
\hline 4HNE & 4-Hydroxy-2-noneal modified protein \\
\hline MAPK & Mitogen-activated protein kinase \\
\hline PCNA & Proliferative cell nuclear antigen \\
\hline PI3K & Phosphoinositide 3-kinase \\
\hline
\end{tabular}

Introduction

It is widely accepted that beta cell function progressively deteriorates in individuals with type 2 diabetes mellitus as described, for example, by the UK Prospective Diabetes 
Study [1]. To prevent diabetic complications, maintenance of strict glycaemic control is necessary, but this requires preservation of beta cell function. On the other hand, human diabetic patients exhibit an early defect in glucosestimulated insulin secretion (GSIS) [2] and autopsy studies have demonstrated reduced beta cell mass in diabetic patients [3]. Thus, development of treatment strategies has focused on ways to improve beta cell function and to prevent beta cell death. Hence, there is increased interest in determining whether newer drugs such as insulinsensitising agents produce sustained improvements in beta cell function [4, 5]. Likewise, agents associated with glucagon-like peptide-1 (GLP-1) have also attracted considerable attention because they may alter the natural history of type 2 diabetes by preserving pancreatic beta cell mass [6-8] and function [9-11].

GLP-1 has several beneficial effects that counteract the pathophysiology of diabetes mellitus. First, GLP-1 is a potent glucose-lowering polypeptide that induces glucosedependent insulin secretion [12, 13] while suppressing glucagon secretion [14, 15]. Second, GLP-1 has extrapancreatic effects, such as delayed gastric emptying [16, 17], appetite suppression [18] and improved insulin sensitivity [19]. Third and last, GLP-1 stimulates beta cell replication [20, 21], neogenesis [22] and differentiation [22], as well as inhibiting beta cell apoptosis via reduction of cellular stress [23-26]. Consequently, GLP-1-related agents are currently regarded as a powerful treatment option for type 2 diabetes [27, 28]. Liraglutide, a novel long-acting GLP-1 derivative, is resistant to dipeptidyl peptidase-IV. Its prolonged effects result from the substitution of Lys for Arg34 and the addition of a glutamic acid and a 16C NEFA to the Lys26 residue of native GLP-1 [29].

To investigate the molecular mechanism by which liraglutide preserves pancreatic beta cell mass, we treated obese diabetic $d b / d b$ mice with liraglutide for 2 days or 2 weeks. We also treated normoglycaemic $\mathrm{m} / \mathrm{m}$ mice with liraglutide for 2 weeks.

\section{Methods}

Animals Male 9-week-old BKS.Cg- $+\operatorname{Lepr}^{d b} /+\operatorname{Lepr}^{d b} / \mathrm{Jcl}$ $(d b / d b)$ mice and BKS. Cg- $m+/ m+/ \mathrm{Jcl}(\mathrm{m} / \mathrm{m})$ mice were purchased (Clea, Tokyo, Japan). They were housed two to three animals per cage in all experiments under controlled ambient conditions and a 14:10 h light/dark cycle with lights on at 07:00 hours. Animals were given free access to drinking water and conventional food (Oriental Yeast, Tokyo, Japan). They received a subcutaneous injection of liraglutide $(200 \mu \mathrm{g} / \mathrm{kg})$ or vehicle (PBS) twice daily (09:00 and 16:00 hours). Doses of the peptides used in the study were based on a review of the literature [7]. Body weight and food intake were monitored weekly from 9 weeks of age. All experiments were approved by the Kawasaki Medical School Animal Experiment Committee (No. 06-062) and were performed in accordance with the Kawasaki Medical School guidelines for animal experiments.

Measurement of biochemical markers Blood samples were collected from the tail vein once per week. Blood glucose was measured immediately using a commercially available enzyme electrode method (FreeStyle; Kissei Pharmaceutical, Nagano, Japan). Plasma was separated and stored at $-80^{\circ} \mathrm{C}$ until use. The concentration of insulin in the plasma was measured using an ELISA kit (Morinaga Institute of Biological Science, Yokohama, Japan) and the plasma triacylglycerol concentration was determined enzymatically (E-Test; Wako, Osaka, Japan).

Insulin tolerance test After the 2 day or 2 week liraglutide treatment in $d b / d b$ mice, an insulin tolerance test was performed by a intraperitoneal injection of insulin ( 2 units $/ \mathrm{kg}$ body weight) after an overnight fast. Blood samples were collected from the tail vein every $30 \mathrm{~min}$ and blood glucose was determined immediately as described above.

Measurement of insulin content in pancreatic islets Pancreatic islets were isolated using the collagenase digestion method as previously described [30]. Briefly, Hanks' balanced salt solution containing $1.5 \mathrm{mg} / \mathrm{ml}$ collagenase (Collagenase $\mathrm{P}$; Roche, Basel, Switzerland) and 10\% (vol./vol.) fetal calf serum was infused into the bile duct. The excised pancreas was transferred to Hanks' balanced salt solution and centrifuged three times for $2 \mathrm{~min}$ each time at 1,100 rpm $(200 \mathrm{~g})$. The final pellet was passed through a metal filter and the filtrate was centrifuged for $22 \mathrm{~min}$ at 2,500 rpm $(1,000 \mathrm{~g})$ using Histopaque-1077 (Sigma, St Louis, MO, USA). The islet samples were stored at $-80^{\circ} \mathrm{C}$ until measurement of insulin content.

Measurement of triacylglycerol content in pancreatic islets Pancreatic islets were isolated as described above and 45-60 of the isolated pancreatic islets were washed twice in PBS, to which $50 \mu \mathrm{l}$ of a high-salt buffer $(2 \mathrm{~mol} / \mathrm{l} \mathrm{NaCl}$, $2 \mathrm{mmol} / \mathrm{l}$ EDTA, $50 \mathrm{mmol} / \mathrm{l}$ sodium phosphate) was added, followed by sonication for $1 \mathrm{~min}$ to disrupt the pancreatic islets. After centrifugation for $5 \mathrm{~min}$ at 12,000 $\mathrm{rpm}(13,000 \mathrm{~g})$, $10 \mu \mathrm{l}$ of the supernatant fraction was mixed with $10 \mu \mathrm{l}$ $t$-butanol plus $50 \mu \mathrm{l}$ Triton X-100-methyl alcohol (1:1). Triacylglycerol content in the pancreatic islets was measured using E-Test (Wako) according to the manufacturer's instructions.

Glucose-stimulated insulin secretion from isolated pancreatic islets Size-matched pancreatic islets were prepared (five 
pancreatic islets per tube) and preincubated in KRB-HEPES buffer containing $5 \mathrm{mg} / \mathrm{ml} \mathrm{BSA}$, $\mathrm{pH} 7.4$, and $95 \% \mathrm{O}_{2} / 5 \%$ $\mathrm{CO}_{2}$ saturated at $37^{\circ} \mathrm{C}$ for $60 \mathrm{~min}$. The supernatant fraction was replaced with a 3.0 or $16.7 \mathrm{mmol} / 1$ glucose solution, and the mixture was incubated for an additional $60 \mathrm{~min}$. The supernatant fraction was recovered and stored at $-80^{\circ} \mathrm{C}$ until the insulin assay was performed.

Immunohistochemistry Pancreas tissue sections $(4 \mu \mathrm{m})$ were stained with haematoxylin-eosin. For immunostaining, the sections were immersed for $15 \mathrm{~min}$ in methanol containing 3\% (vol./vol.) hydrogen peroxide to block endogenous peroxidase activity. After rinsing with PBS $(10 \mathrm{mmol} / \mathrm{l}, \mathrm{pH} 7.0)$, the sections were incubated for $1 \mathrm{~h}$ with a mixture of antibodies (rabbit anti-glucagon antibody: anti-somatostatin antibody 1:1; Nichirei, Tokyo, Japan) at $25^{\circ} \mathrm{C}$. Tissue sections were also incubated for $14 \mathrm{~h}$ at $4^{\circ} \mathrm{C}$ with either a mouse anti-insulin monoclonal antibody, an anti-proliferative cell nuclear antigen (PCNA) monoclonal antibody (Nichirei) or a mouse anti-4-hydroxy-2-noneal modified protein (4HNE) monoclonal antibody $(25 \mu \mathrm{g} / \mathrm{ml}$; Japan Institute for the Control of Aging, Shizuoka, Japan). After rinsing with PBS, simple stain diaminobenzidine solution (Nichirei) was added and the mixture was incubated for $7 \mathrm{~min}$ at $25^{\circ} \mathrm{C}$. The sections were counterstained with haematoxylin. To investigate cell apoptosis, a TUNEL assay was performed using a colorimetric apoptotic detection system (DeadEnd; Promega, Madison, WI, USA), as described previously [31].

Morphometric analysis The image analysis software NIH Image (Version 1.61; http://rsbweb.nih.gov/ij/) was used to calculate the entire pancreatic area, islet area and glucagonand somatostatin-positive cells, and also to determine the relative islet area and the relative beta cell area. Using 15 sections (i.e. five sections from three different areas of the pancreas) for each group of mice, beta cell mass was estimated by the following formula: beta cell mass $(\mathrm{mg})=$ the pancreas weight $(\mathrm{mg}) \times$ per cent pancreatic islet area $\times$ percent beta cell count.

Laser capture microdissection According to our previously established procedure [32], frozen, $8 \mu \mathrm{m}$ thick tissue slices were immediately stained and subjected to laser capture microdissection. After tissue staining, the islets were irradiated with a laser using the PixCell system (Arcturus, Mountain View, CA, USA). The peripheral area was first removed and then the beta-cell-rich core area was collected.

Real-time PCR RNA was extracted using an RNA isolation kit (PicoPure PN 12206-01; Arcturus). TaqMan reverse transcription reagents (N808-0234; Applied Biosystems, Foster, CA, USA) were used for reverse transcription and random hexamers were used as primers for cDNA synthesis. The primers were designed using Primer Express (Applied Biosystems) and were based on mRNA sequences downloaded from the GenBank nucleotide database (www.ncbi.nlm.nih.gov/nuccore).

A reaction solution was prepared by combining $0.5 \mu \mathrm{l}$ of the sample, $1 \mu \mathrm{l}$ of a $50 \mathrm{nmol} / \mathrm{l}$ primer solution, $5 \mu \mathrm{l}$ Sybr Green PCR Master Mix (Applied Biosystems) solution and $3.5 \mu$ diluent. Dissociation curve analysis was performed for each experiment to determine the dissociation temperature and the size of the PCR products was confirmed by agarose gel electrophoresis. We examined gene expression in the core area of the pancreatic islets, selecting primary genes for which a statistically significant difference between the groups in the first gene expression experiment had been observed. The genes analysed in the present study were those associated with cell differentiation (Hlxb-9 [also known as Mnxl], Hes1, Neurod [also known as Neurod1] and $P d x 1)$, cell proliferation $(C y c D$ and Erk-1 [also known as Mapk3]), endoplasmic reticulum (ER) stress (Xbpl), antioxidative stress (Cat and Gpx), lipid synthesis (Srebp-1c [also known as Srebfl] and Fas) and cell apoptosis (Bcl2, Casp $8, C a s p 3$ and $C a d$ ). To quantify gene expression, $2^{\Delta \mathrm{C}_{\mathrm{t}}}$ was calculated using 18S rRNA as an internal control.

Statistical analysis All data are presented as means \pm SEM. A Mann-Whitney $U$ test was used to test for differences among multiple groups, with $p<0.05$ regarded as significant. The statistical analyses were performed with StatView (version 5; SAS, Cary, NC, USA).

\section{Results}

Metabolic variables in db/db mice with chronic liraglutide treatment After 1 week of treatment, liraglutide significantly decreased food intake $(23.7 \pm 1.6$ vs $39.8 \pm 0.8 \mathrm{~g}$ per week, $p<0.0001$; Fig. 1a) and suppressed body weight gain (41.3 \pm 0.4 vs $43.3 \pm 0.5 \mathrm{~g}, p<0.05$; Fig. $1 b)$ in $d b / d b$ mice compared with vehicle-treated mice. Liraglutide also reduced fasting glucose $(7.0 \pm 0.4$ vs $9.4 \pm 0.6 \mathrm{mmol} / 1$, $p<0.05$; Fig. 1c) and insulin concentrations $(567.9 \pm 51.6$ vs $1,032 \pm 86.1 \mathrm{pmol} / 1, p<0.01$; Fig. $1 \mathrm{~d})$ in $d b / d b$ mice after 1 week of treatment. These effects were sustained by prolonged intervention with liraglutide until 2 weeks, at which time the liraglutide-treated group had a significant improvement in hypertriacylglycerolaemia $(1.3 \pm 0.03$ vs $1.5 \pm 0.07 \mathrm{mmol} / 1, p<0.01$; Fig. $1 \mathrm{e})$. We also found that brief liraglutide treatment, i.e. for 2 days, resulted in similar metabolic improvements (Fig. 2a, b, d). The exception was fasting insulin, which was increased by 2 days of liraglutide treatment compared with vehicle $(826.1 \pm 86.1$ vs $567.9 \pm$ $34.4 \mathrm{pmol} / 1, p<0.05$; Fig. 2c). Insulin sensitivity in $d b / d b$ 
Fig. 1 Metabolic variables in diabetic $d b / d b$ mice treated for 2 weeks with vehicle (diamonds) or liraglutide (squares). a Food intake, (b) body weight, (c) Fasting blood glucose, (d) fasting plasma insulin concentration,

(e) fasting plasma triacylglycerol concentration and (f) insulin sensitivity assessed by an i.p. insulin tolerance test. Results of the insulin tolerance test are expressed as a percentage relative to the basal blood glucose concentration before insulin administration. $n=7$ for each group; ${ }^{*} p<0.05$, $* * p<0.01, * * * p<0.001$; ${ }^{\dagger} p<0.005$
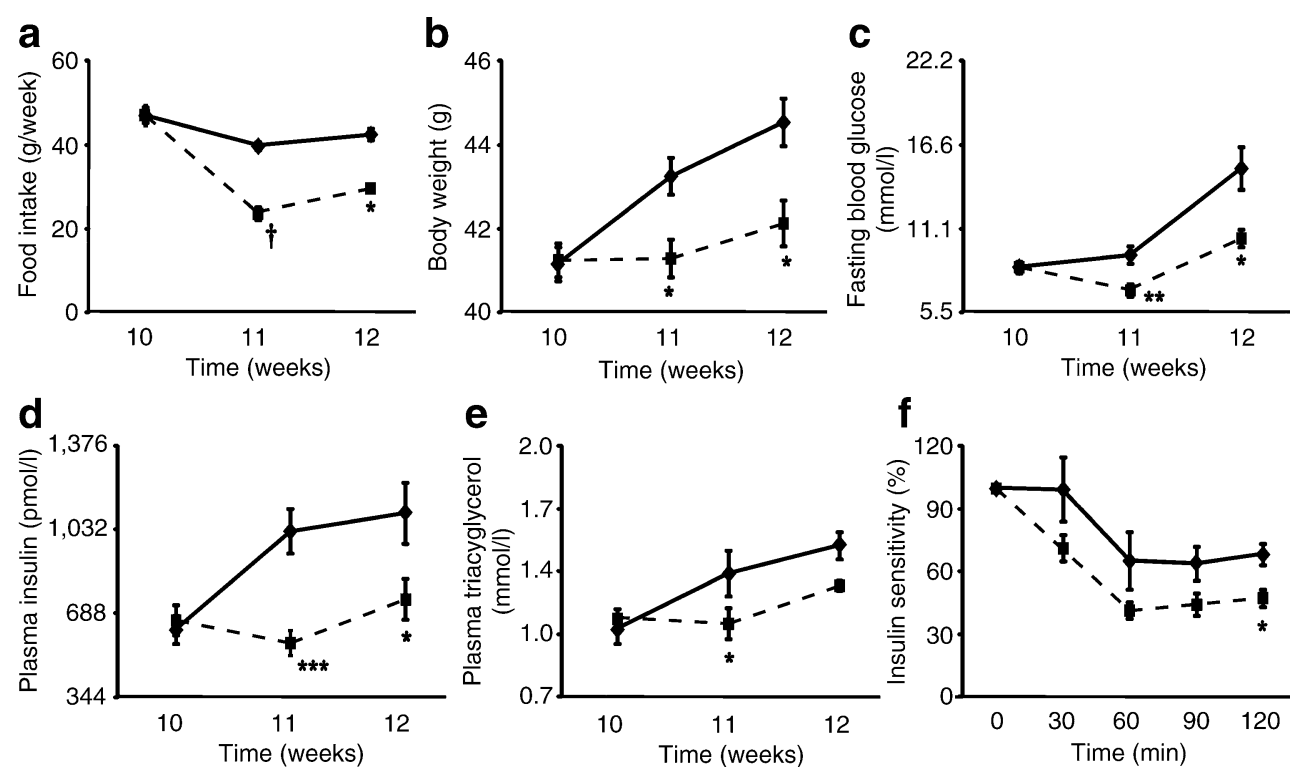

mice was improved only after 2 weeks of liraglutide treatment (Figs 1f, 2e).

Islet function and morphology in $\mathrm{db} / \mathrm{db}$ mice treated with liraglutide To investigate whether 2 weeks of liraglutide treatment exerted beneficial effects on the pancreatic islets of $d b / d b$ mice, we first subjected isolated pancreatic islets to morphological analysis and immunostaining with antibodies against glucagon and somatostatin. While liraglutide treatment in $d b / d b$ mice conserved the normal morphology of pancreatic islets, in which glucagon- and somatostatinpositive cells were observed in the periphery, vehicle treatment disrupted these structures (Fig. 3a). In addition, beta cell mass was significantly increased in liraglutide- treated $d b / d b$ mice, compared with vehicle-treated mice ( $7.7 \pm 0.7$ vs $4.9 \pm 0.5 \mathrm{mg}, p<0.01$; Fig. $3 \mathrm{~b}$ ).

After the 2 week intervention, islet insulin content in liraglutide-treated $d b / d b$ mice was greater than that in $d b / d b$ mice treated with vehicle for 2 weeks $(33.7 \pm 2.3$ vs $17.2 \pm$ $2.1 \mathrm{ng} /$ islet, $p<0.01$; Fig. 3i). Although islet insulin content in vehicle-treated $d b / d b$ mice tended to decrease with age ( 2 days $24.7 \pm 2.7$ vs 2 weeks $17.2 \pm 2.1 \mathrm{ng} /$ islet, $p=0.1$; Fig. 3i), that in mice treated with liraglutide for 2 weeks was increased compared with mice treated with liraglutide for 2 days ( 2 weeks $33.7 \pm 2.3$ vs 2 days $27.0 \pm 1.7 \mathrm{ng}$ /islet, $p<0.05$; Fig. 3i).

After 2 weeks of liraglutide treatment, insulin secretion was increased in response to $16.7 \mathrm{mmol} / \mathrm{l}$ glucose, but not
Fig. 2 Metabolic variables in diabetic $d b / d b$ mice treated for 2 days with vehicle (black bar, diamonds) or liraglutide (white bar, black squares). a Body weight (BW) change, (b) fasting blood glucose, (c) fasting plasma insulin concentration, (d) fasting plasma triacylglycerol concentration and (e) insulin sensitivity assessed by i.p. insulin tolerance test. Results of the tolerance test are expressed as a percentage relative to the basal blood glucose concentration before insulin administration. $n=11$ for each group; ${ }^{*} p<0.05, * * * p<0.001$
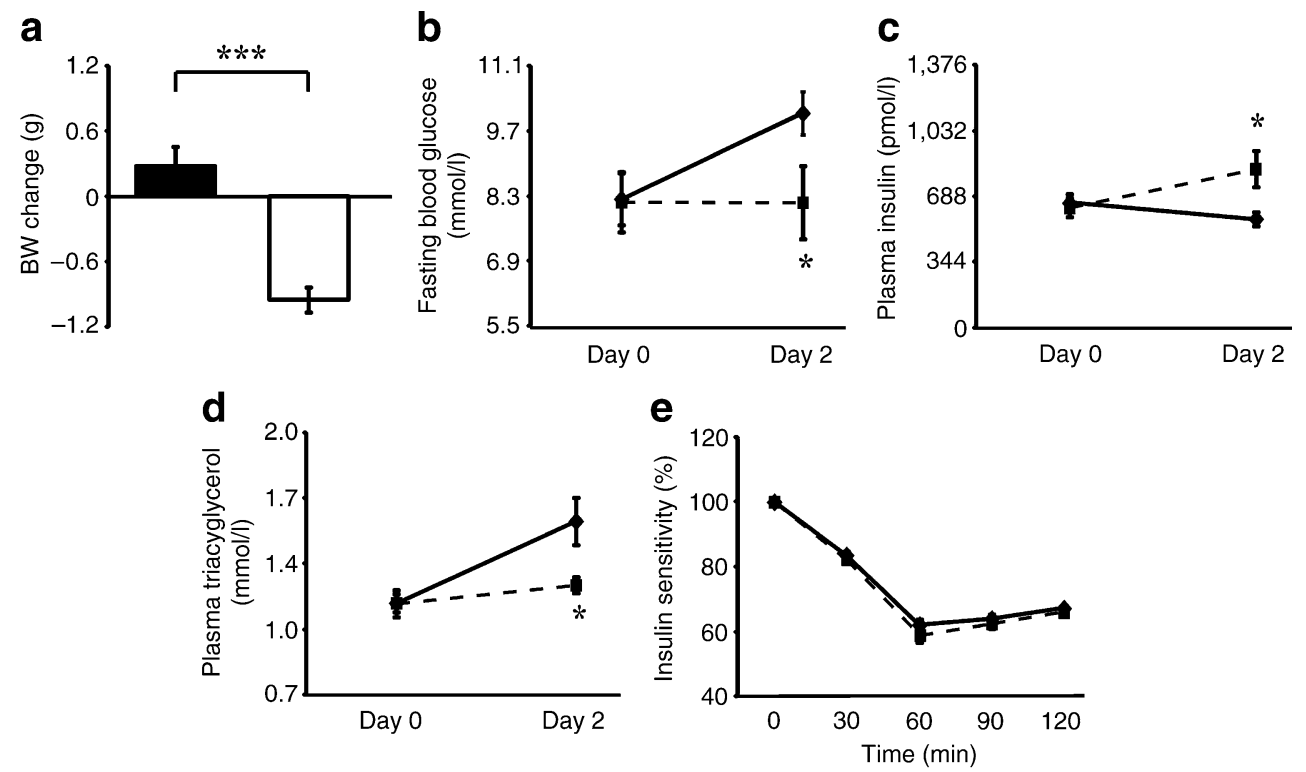
a

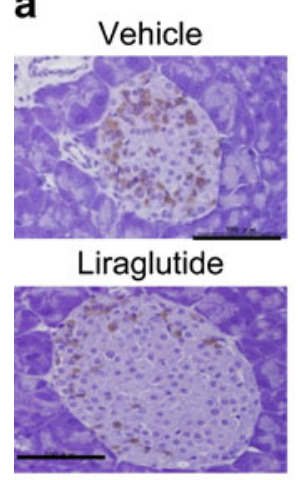

e Vehicle

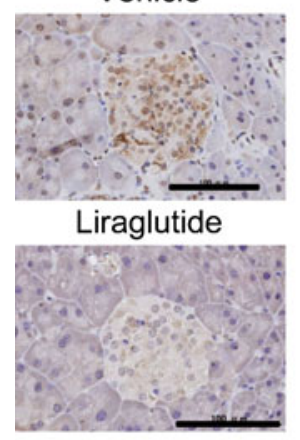

b

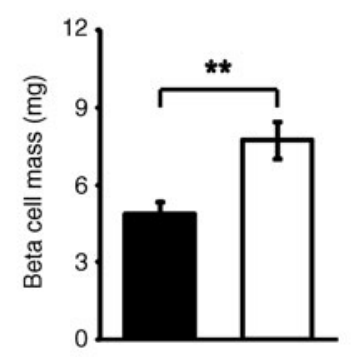

$\mathbf{f}$

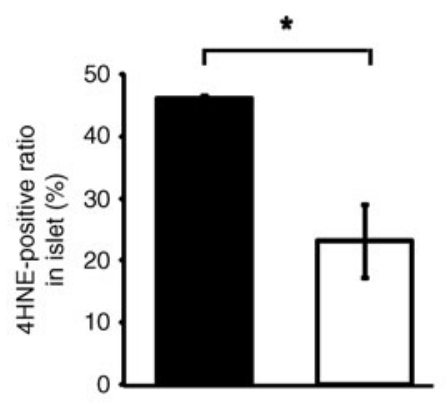

c

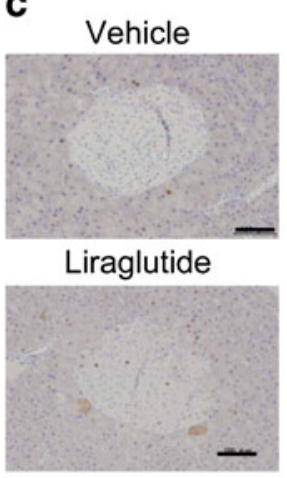

g

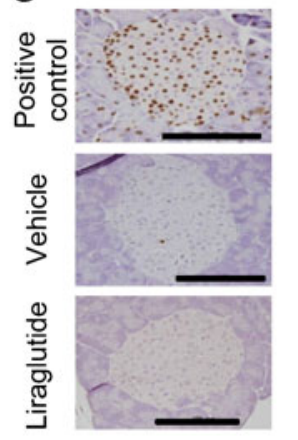

d

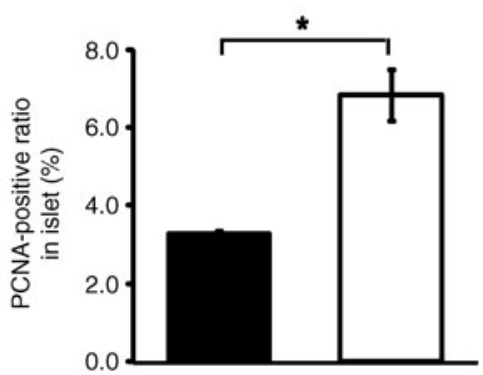

h

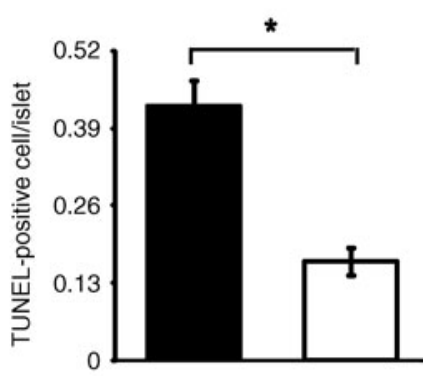

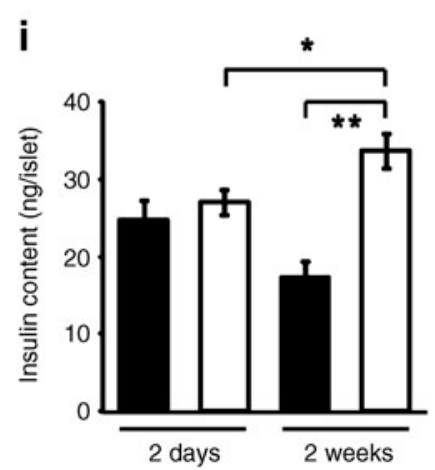

j

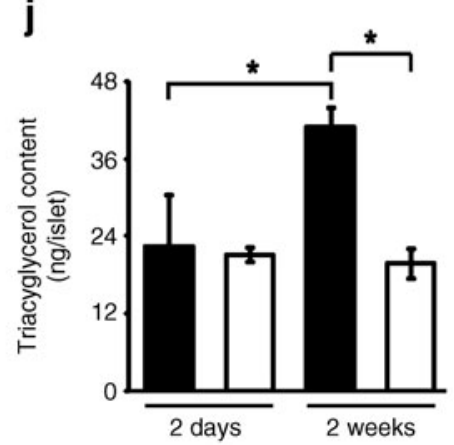

$\mathbf{k}$

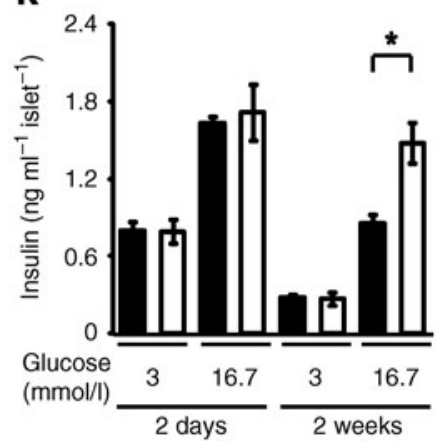

Fig. 3 Islet morphology and function in $d b / d b$ mice treated with vehicle (black bars) or liraglutide (white bars) for 2 days or 2 weeks. a Haematoxylin-eosin staining, followed by double immunohistochemical staining with antibodies against glucagon and somatostatin. Scale bars $100 \mu \mathrm{m}$. b Beta cell mass, measured as described; $n=5$ (a, b). c Immunohistochemical staining with antibodies against PCNA, quantified (d) as ratio. e, f 4-HNE and (g, h) TUNEL assays and quantification as indicated. $\mathbf{c}-\mathbf{h} n=3$ for each assay, scale bars $100 \mu \mathrm{m}$. The proportion of cells positive for PCNA (c, d) and

to $3 \mathrm{mmol} / \mathrm{l}(1.5 \pm 0.2 \mathrm{vs} 0.9 \pm 0.1 \mathrm{ng} / \mathrm{ml}$ per islet, $p<0.05$; Fig. $3 \mathrm{k})$. However, 2 days of liraglutide treatment had no effect on insulin secretion, irrespective of glucose concentration (Fig. 3k). These results suggest that chronic liraglutide treatment improved the reactivity of pancreatic beta cells in response to the higher glucose concentration.

Next, we examined the effect of liraglutide treatment on islet triacylglycerol content, which was not affected by 2 days of liraglutide treatment (Fig. 3j), although hyper-
4-HNE (e, f) was measured in each islet and expressed as average proportion for a minimum of 50 islets from each experimental animal. DNase-treated cells were used as a positive control in the TUNEL assay $(\mathbf{g}, \mathbf{h})$, with results of the TUNEL assay expressed as the average number of TUNEL-positive cells per islet by assessing a minimum of 50 islets from each experimental animal. i Islet insulin content and (j) islet triacylglycerol content; $n=5$. k GSIS was assessed by use of lower and higher glucose concentrations $(3 \mathrm{mmol} / \mathrm{l}$ and $16.7 \mathrm{mmol} / 1) ; n=5 .{ }^{*} p<0.05, * * p<0.01$

triacylglycerolaemia was improved (Fig. 2d). However, the accumulation of triacylglycerol in the pancreatic islets was prevented by 2 weeks of liraglutide treatment (Fig. 3j), despite an increase in islet triacylglycerol content with ageing in vehicle-treated mice.

A morphological examination was used to study the mechanisms involved in the restoration of pancreatic beta cell mass by liraglutide in $d b / d b$ mice. Histological sections of the pancreatic islet were stained by an antibody specific 
for PCNA and the proportion of antibody-positive cells was measured to evaluate the proliferative effect on pancreatic islets. Liraglutide-treated mice exhibited a significant increase in PCNA-positive cells in pancreatic islets (Fig. 3c, d). Oxidative stress, which was evaluated by scoring 4-HNE-positive cells in pancreatic islets, was reduced in the pancreatic islets of liraglutide-treated mice (Fig. 3e, f), while cellular apoptosis, analysed by a TUNEL assay, was suppressed (Fig. 3g, h).

Effect of liraglutide on gene expression in pancreatic beta cells of $\mathrm{db} / \mathrm{db}$ mice Both 2 weeks and 2 days of liraglutide treatment significantly augmented expression of genes involved in cellular differentiation (Hlxb-9, Neurod and $P d x 1$; Fig. 4a, c, d, g, i, j) and significantly reduced expression of an anti-differentiation gene (Hesl) in pancreatic beta cells of $d b / d b$ mice (Fig. $4 \mathrm{~b}, \mathrm{~h}$ ). The expression of genes involved in cellular proliferation ( $C y c D$ and Erk-1) was also increased significantly in $d b / d b$ mice treated with liraglutide for 2 weeks, with similar results obtained in mice treated for 2 days (Fig. 4e, f, k, 1). Liraglutide also significantly increased expression of the anti-apoptotic Bcl2 gene (Fig. 4m, q) and reduced expression of proapoptotic genes (Casp8, Casp3 and $\mathrm{Cad}$ ) in both treatment regimens (Fig. 4n, o, p, r, s, t).

In contrast, chronic but not acute liraglutide treatment significantly increased the expression of genes involved in anti-oxidative stress (Cat and Gpx; Fig. 4u, v, z, aa) and significantly reduced those related to ER stress ( $X b p 1$; Fig. 4w, bb) and lipid synthesis (Srebp-1c and Fas) in beta cells of $d b / d b$ mice (Fig. $4 \mathrm{x}, \mathrm{y}, \mathrm{cc}$, dd). The expression profile of Srebp-1c and Fas (Fig. 4x, y, cc, dd), which was consistent with islet triacylglycerol content (Fig. 3j), indicated that liraglutide alleviates the lipotoxicity experienced by beta cells in a time-dependent fashion. Together, these results suggest that liraglutide directly accelerates cellular differentiation and proliferation, and inhibits apoptosis via a reduction in oxidative and ER stress mediated by improvements in glucolipotoxicity.

Impact of liraglutide on metabolism in normoglycaemic mice We next investigated the effect of liraglutide in normoglycaemic $\mathrm{m} / \mathrm{m}$ mice, which were treated with or without liraglutide for 1 week. Food intake in $\mathrm{m} / \mathrm{m}$ mice, compared with the vehicle-treated group, was significantly reduced by liraglutide treatment $(21.1 \pm 0.8$ vs $27.9 \pm 1.0 \mathrm{~g} /$ week, $p<0.05$; Fig. 5a), as was body weight gain $(20.1 \pm 0.2$ vs $22.2 \pm 0.9 \mathrm{~g}$, $p<0.05$; Fig. 5b). These effects were sustained by prolonged liraglutide treatment for up to 2 weeks, but were not correlated with metabolic variables, such as fasting concentrations of blood glucose, insulin and triacylglycerol, which did not differ statistically between liraglutide-treated and vehicle-treated $\mathrm{m} / \mathrm{m}$ mice (Fig. $5 \mathrm{c}-\mathrm{e}$ ).
Effect of liraglutide on morphology, function and gene expression of pancreatic beta cells in normoglycaemic mice In $\mathrm{m} / \mathrm{m}$ mice, beta cell mass and islet insulin content were significantly increased by liraglutide treatment $(1.0 \pm$ 0.1 vs $0.7 \pm 0.1 \mathrm{mg}, p<0.01 ; 59.0 \pm 3.7$ vs $44.4 \pm 3.9 \mathrm{ng} /$ islet, $p<0.05$; Fig. 6a, b). The increases in beta cell mass and islet insulin content were associated with improvements in GSIS in isolated islets in response to $16.7 \mathrm{mmol} / 1$ glucose $(1.6 \pm 0.1$ vs $1.2 \pm 0.03 \mathrm{ng} / \mathrm{ml}$ per islet, $p<0.05$; Fig. $6 \mathrm{c})$ in the liraglutide-treated group compared with the vehicle-treated group.

The number of PCNA-positive cells was significantly increased (Fig. 6d), suggesting that the proliferation of pancreatic islets was upregulated in liraglutide-treated $\mathrm{m} / \mathrm{m}$ mice. Nevertheless, the numbers of 4-HNE-positive and TUNEL-positive cells in the pancreatic islets did not differ between liraglutide- and vehicle-treated $\mathrm{m} / \mathrm{m}$ mice (Fig. 6e, f). At the level of mRNA expression, $m / m$ mice treated with liraglutide for 2 weeks experienced a significant increase in expression of genes involved in cellular differentiation (Hlxb-9, Neurod and Pdx1; Fig. 7a, c, d) and proliferation (Erk-1 and $C y c D$; Fig. 7e, f), along with a significant reduction in expression of an antidifferentiation gene (Hes1; Fig. 7b). The expression of mRNA for genes associated with cell apoptosis, antioxidative stress, ER stress and lipid synthesis was not statistically different between liraglutide- and vehicletreated mice (Fig. 7g-o). These results suggest that liraglutide affects beta cell mass by stimulating cellular differentiation and proliferation without affecting blood glucose, insulin or triacylglycerol concentrations.

\section{Discussion}

In the present study, we investigated the effects of liraglutide on obese diabetic mice. We found that the beta cell mass of $d b / d b$ mice was increased by long-term liraglutide treatment. These results are essentially consistent with previous reports describing a stimulatory effect on beta cell mass of exendin-4, a potent GLP-1 receptor agonist, in a partial pancreatectomy rat model of type 2 diabetes [20] and of liraglutide, the long-acting GLP-1 derivative, in diabetic $d b / d b$ mice [7].

The present results demonstrate that short- and long-term treatment with liraglutide affected mRNA expression of Hlxb-9, Hes 1 and Neurod in the core of islets in diabetic $d b / d b$ mice. The roles of several genes with well defined functions in pancreatic development, such as those mentioned above (Hlxb9, Hes-1 and Neurod) have not been previously studied in the adult pancreas. On the other hand, previous studies have suggested that the Notch signal through hairy and enhancer of split-1 (HES1) is activated 

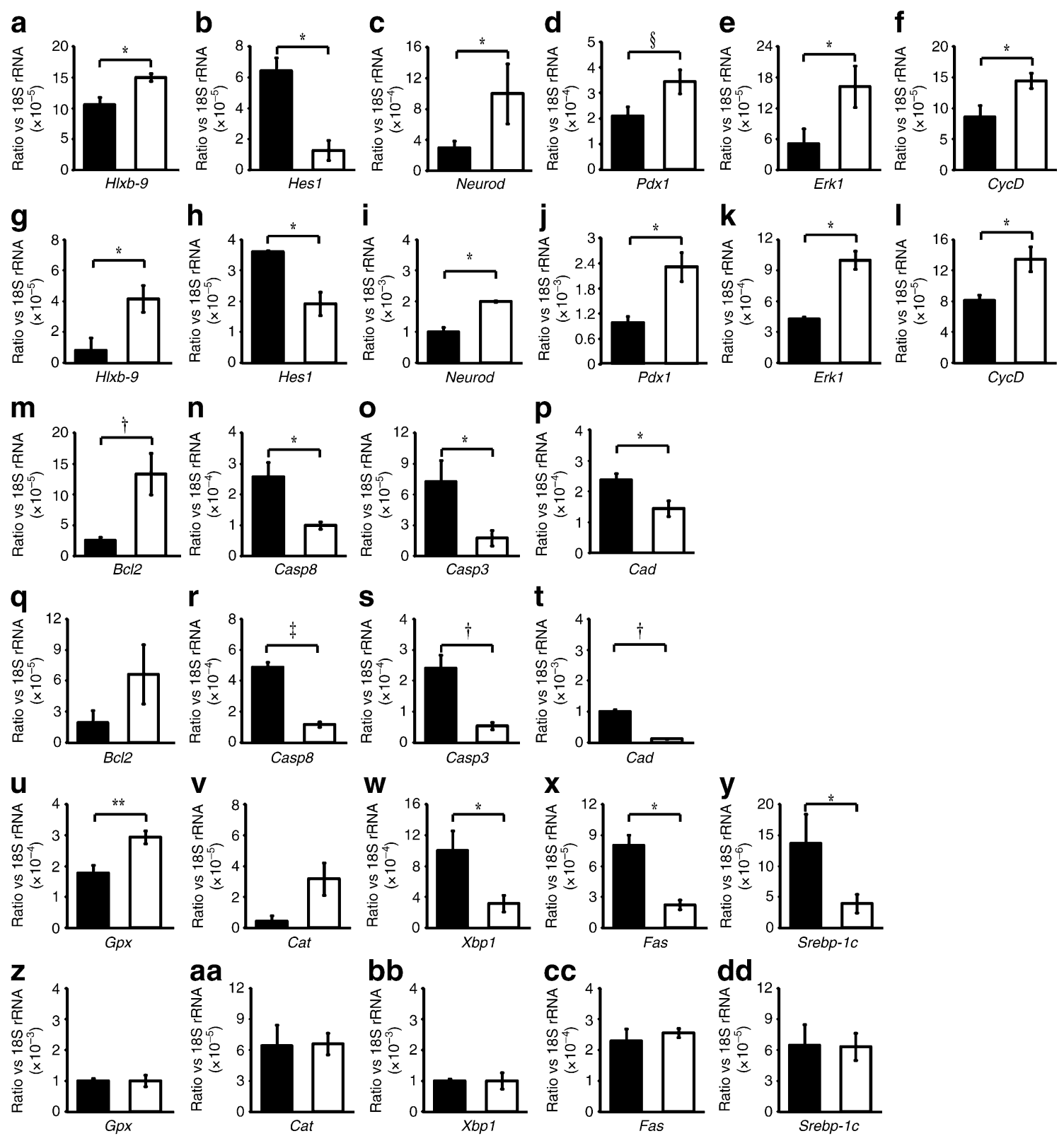

Fig. 4 Gene expression in the core area of islets in $d b / d b$ mice treated with vehicle (black bars) or liraglutide (white bars). a-f Expression of genes involved in cell differentiation and proliferation after 2 weeks and (g-l) 2 days of treatment. a, g Hlxb-9, (b, h) Hes1, (c, i) Neurod, (d, j) $P d x l,(\mathbf{e}, \mathbf{k})$ Erk1, (f, l) $C y c D$. m-t Expression of genes involved in pro-apoptosis and anti-apoptosis after 2 weeks $(\mathbf{m}-\mathbf{p})$ and 2 days

even in the adult pancreas in conditions associated with cell regeneration, such as inflammation and neoplasia in the pancreas $[33,34]$. In addition, a recent in vitro study also demonstrated that HES1 is involved in determining the beta cell fate of adult human beta cells [35]. These findings suggest the possibility that genes associated with an early stage of endocrine pancreas development are expressed in adult $d b / d b$ mice and that liraglutide affects the expression of those genes. However, the present results cannot be $(\mathbf{q}-\mathbf{t})$ of treatment. m, q $B c l 2,(\mathbf{n}, \mathbf{r}) \operatorname{Casp} 8,(\mathbf{o}, \mathbf{s}) \operatorname{Casp} 3,(\mathbf{p}, \mathbf{t}) C a d$. u-dd Expression of genes involved in anti-oxidative stress, ER stress and lipid synthesis after 2 weeks $(\mathbf{u}-\mathbf{y})$ and 2 days $(\mathbf{z}-\mathbf{d d d})$ of treatment. u, z Gpx, (v, aa) Cat, (w, bb) Xbp1, (x, cc) Fas, (y, dd) Srebp-1c. $n=4$ for each group; ${ }^{*} p<0.05,{ }^{* *} p<0.01 ;{ }^{\dagger} p<0.005 ;{ }^{\sharp} p<0.0001 ;{ }^{\S} p=0.08$

regarded as conclusive, and further studies will be required to elucidate this issue.

In this study, cell proliferation related to $C y c D$ and Erk-1 gene expression was readily upregulated in diabetic and normoglycaemic mice treated with liraglutide for 2 days. Immunohistochemical analysis of the pancreatic islets suggested that enhancement of cellular proliferation might be an underlying mechanism that accounts for the restorative effects of GLP-1 on pancreatic beta cell mass. These 
Fig. 5 Metabolic variables in normoglycaemic $\mathrm{m} / \mathrm{m}$ mice treated with vehicle (diamonds) or liraglutide (squares). a Food intake, (b) body weight, (c) fasting blood glucose, (d) fasting plasma insulin concentration and (e) fasting plasma triacylglycerol concentration. $n=5$ for each group; ${ }^{*} p<0.05,{ }^{*} p<0.01$
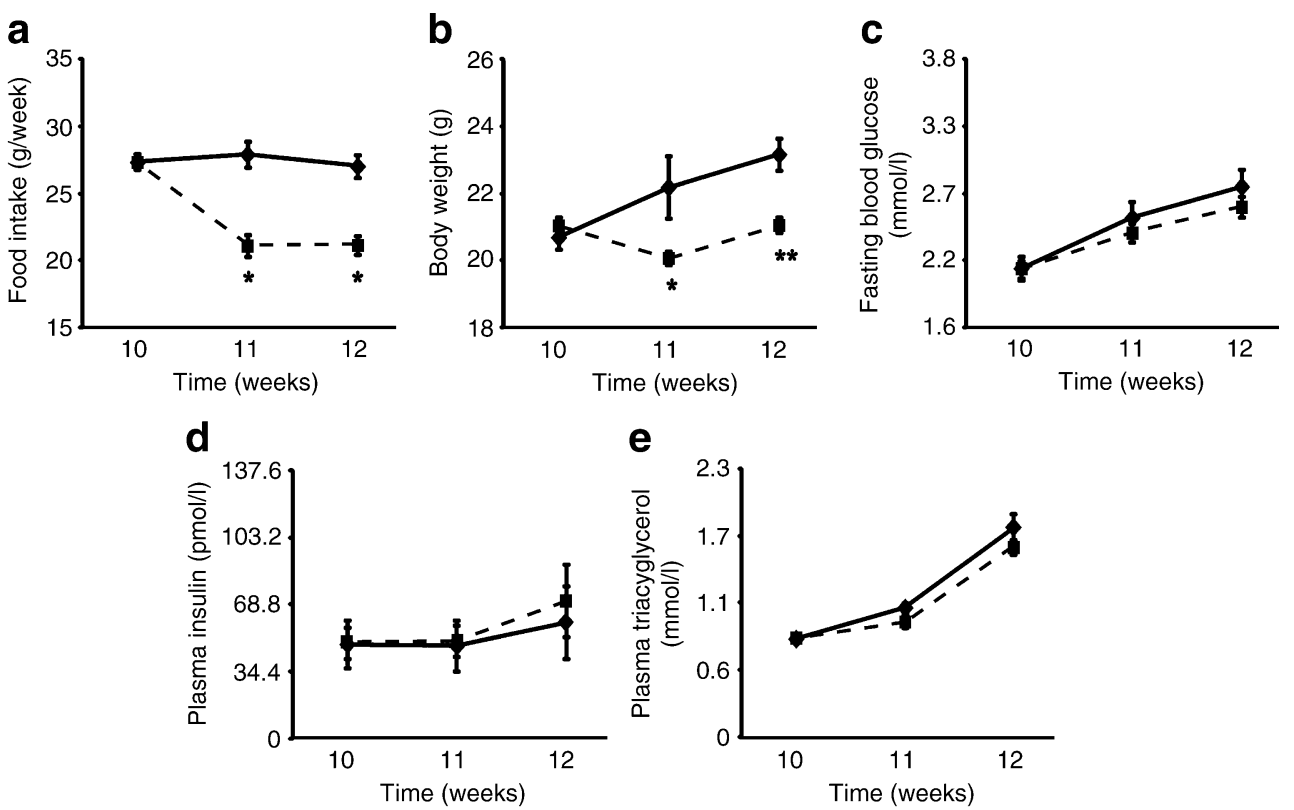

results strongly support the hypothesis that liraglutide affects pancreatic beta cell mass by directly stimulating cellular proliferation. Interestingly, a previous study demonstrated that pancreatic beta cell mass in non-diabetic rats was significantly increased after 1 week of liraglutide treatment, but no different from that in control animals after 6 weeks of treatment, indicative of a temporary effect on beta cell mass [36]. This result suggests that the effect of liraglutide on beta cell kinetics is acute and temporary in non-diabetic conditions.

The binding of GLP-1 to its receptors activates adenylate cyclase and the cyclic AMP/protein kinase A signalling pathway. Additionally, GLP-1 activates phosphoinositide 3kinase (PI3K), p42 mitogen-activated protein kinase (MAPK) and the epidermal growth factor receptor [37-39]. Furthermore, activation of the transcription factor for $P d x 1$

Fig. 6 Islet morphology and islet function in $\mathrm{m} / \mathrm{m}$ mice treated for 2 weeks with vehicle (black bars) or liraglutide (white bars). a Pancreatic beta cell mass, (b) islet insulin content and (c) GSIS. d Immunohistochemical staining of the pancreatic islet with antibodies against PCNA, (e) 4-HNE and (f) TUNEL. $n=4$ for each group; ${ }^{*} p<0.05, * * p<0.01$
[38], p38 MAPK and protein kinase C-zeta [40] reportedly plays a role in GLP-1-induced DNA synthesis and replication. Thus there is emergent evidence for extensive cross-talk between the G-protein-coupled receptor and tyrosine kinasecoupled receptor signalling pathways in beta cells. The results of the present study show that modulation of the $C y c D$ gene is involved in the liraglutide-induced increase in beta cell mass, presumably through the MAPK pathway. We also found that cellular differentiation is affected by liraglutide via upregulation of $P d x 1$, which is located downstream of the $\mathrm{PI} 3 \mathrm{~K}$-protein kinase B-forkhead box O1 pathway.

Liraglutide modified the expression of genes related to cell apoptosis such as Bcl2, Casp8, Casp3 and Cad in $d b / d b$ mice during short- and long-term treatment, whereas mRNA levels of these genes were not altered in normoglycaemic $\mathrm{m} / \mathrm{m}$ mice, suggesting that liraglutide directly suppressed
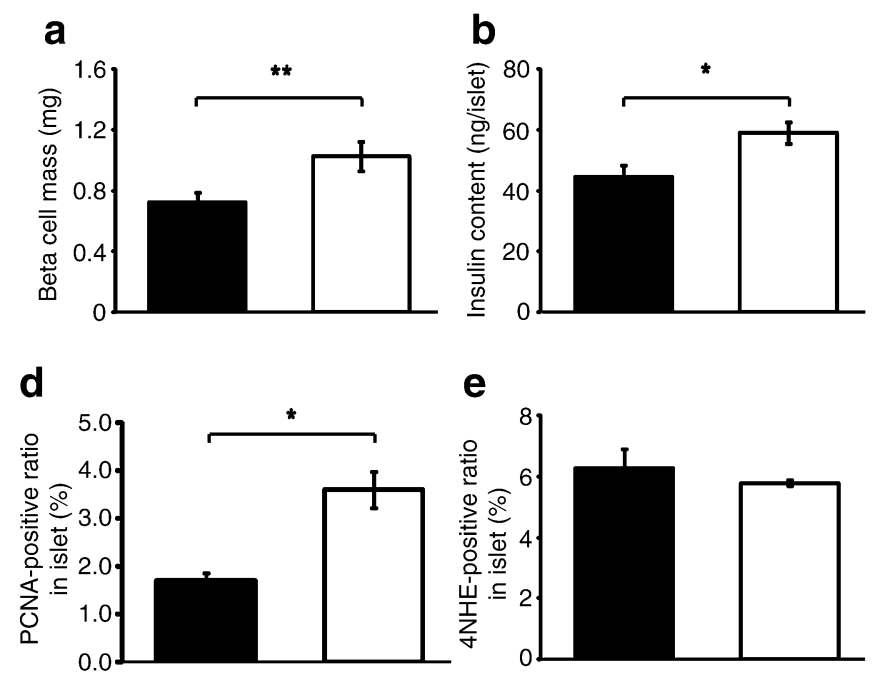
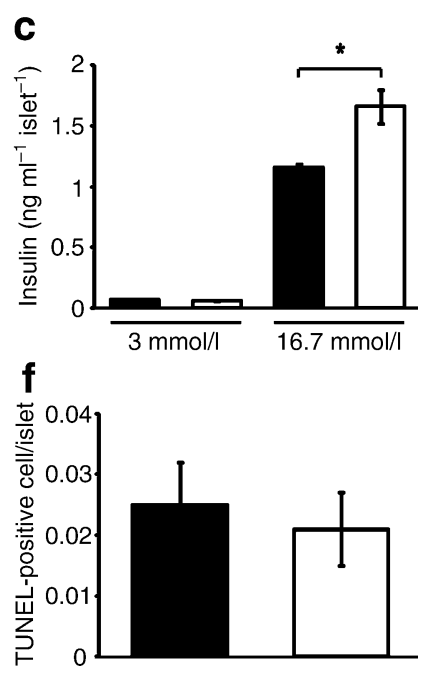

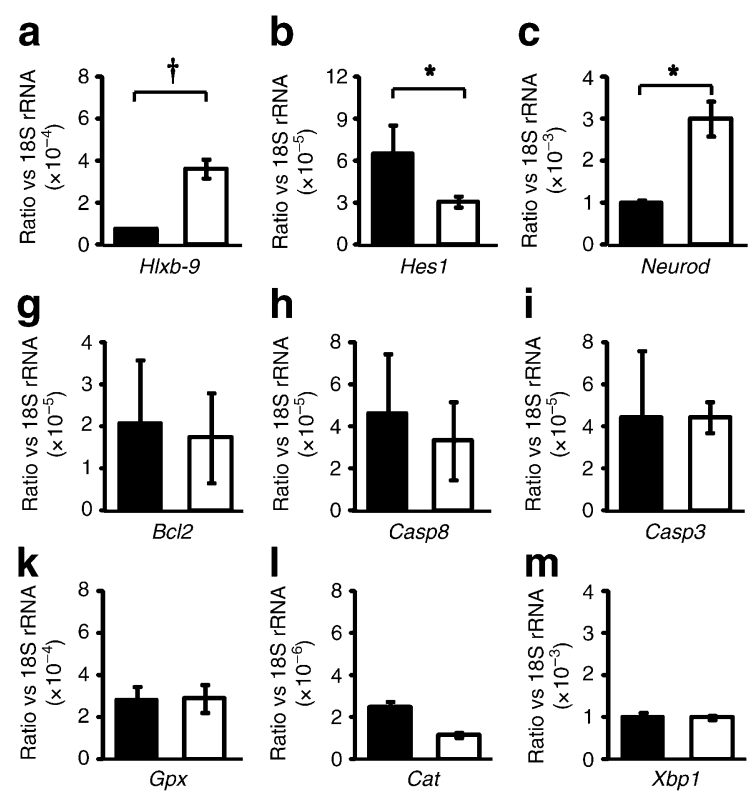

Fig. 7 Gene expression in the core area of islets in $\mathrm{m} / \mathrm{m}$ mice treated with vehicle (black bars) or liraglutide (white bars) for 2 weeks. a-f Expression of genes involved in cell differentiation and proliferation, i.e. (a) Hlxb-9, (b) Hes1, (c) Neurod, (d) Pdxl, (e) Erk1 and (f) CycD. g-j Expression of genes involved in cell apoptosis, i.e. (g) Bcl2, (h)

beta cell apoptosis in mice under hyperglycaemic conditions. In a previous report, extracellular signal-regulated kinase (ERK)1/2 regulated $B c l 2$ gene expression and protein production, as well as the activity of caspase 3 through the regulation of cyclic AMP-responsive element-binding protein [41]. Furthermore, the extracellular matrix directly suppressed caspase 8 activity through regulation of the ERK but not the PI3K pathway in pancreatic beta cells [42]. These results indicate that liraglutide may have a direct antiapoptotic effect, which is at least partly mediated by ERK.

With regard to the effect of GLP-1 on oxidative stress, Tews and co-workers [26] reported that exendin-4 directly reduces oxidative stress through counterregulation of the reduced abundance of electron transport chain proteins in INS-1 beta cells. In the present study, immunohistological analysis with anti-4-HNE staining and the TUNEL assay showed that 2 weeks of liraglutide treatment inhibited cellular oxidative stress and apoptosis of the pancreatic islets in diabetic $d b / d b$ mice. We also showed that 2 weeks, but not 2 days of liraglutide treatment suppressed expression of Cat and Gpx. The expression of Srebp-1c and Fas mRNAs, as well as islet triacylglycerol content were also decreased only by the 2 week liraglutide treatment regimen. These results suggest that, in contrast to the action of exendin- 4 in cultured cell lines, the improvements in oxidative stress observed with liraglutide treatment in $d b / d b$ mice are secondary to improvements in glucolipotoxicity.

The inhibitory effect of long-term liraglutide treatment on expression of $X b p 1$ in the core area of pancreatic islets,
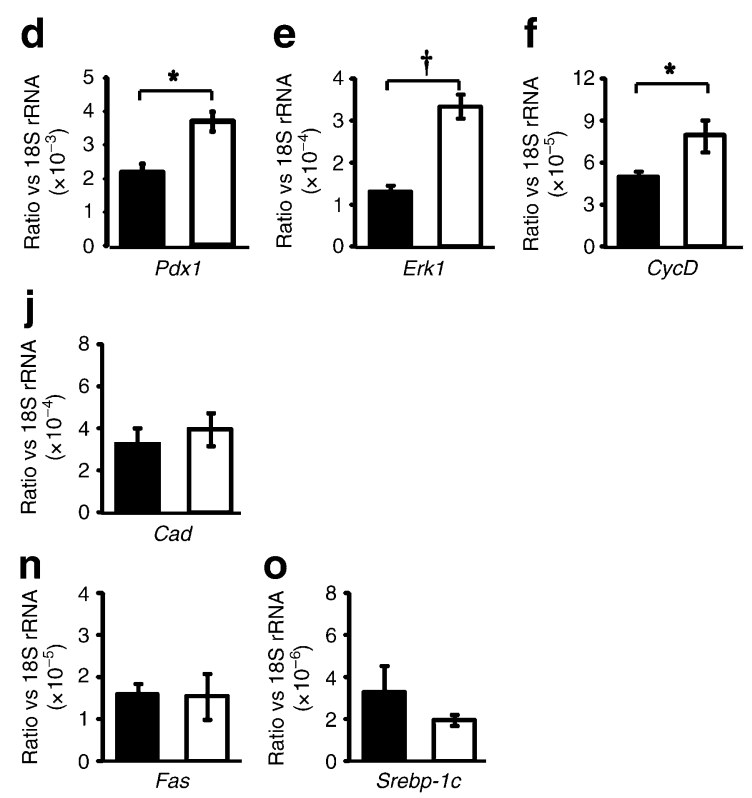

Casp8, (i) Casp3 and (j) Cad. k-o Expression of genes involved in anti-oxidative stress, ER stress and lipid synthesis, i.e. (k) Gpx, (l) Cat, (m) Xbpl, (n) Fas and (o) Srebp-1c. $n=4$ for each group; $* p<0.05 ;{ }^{\dagger} p<0.005$

which should reflect a decrease in the unfolded protein accumulated in the ER of pancreatic beta cells, is essentially consistent with the findings of Yusta et al., who reported that chronic administration of exendin-4 decreased expression of Chop (also known as Ddit3) and spliced $X b p 1$ in the pancreatic islets of $d b / d b$ mice [43]. They also found that exendin-4 potentiated the induction of activating transcription factor 4 , a transcription factor mediated by phosphorylated eukaryotic translation initiation factor $2 \alpha(\mathrm{eIF} 2 \alpha)$, in the INS-1 beta cell in a manner that is dependent on protein kinase A, accelerating recovery from ER stress-mediated translational repression by growth arrest and DNA-damage-inducible 34, which promotes eIF $2 \alpha$ dephosphorylation [43]. Contrary to the in vitro findings reported by Yusta et al. [43], the present in vivo study demonstrated that even short-term liraglutide treatment did not affect expression of Xbp1 in hyperglycaemic mice. The different study conditions, in vivo and in vitro experiments, may have led to these different results.

Fehmann and Habener demonstrated a stimulatory effect of GLP-1 on proinsulin biosynthesis in insulinoma beta TC-1 cells [9]. In the present study, we found that liraglutide enhanced the responsiveness of beta cells to a glucose challenge in diabetic and normoglycaemic mice. These results are essentially consistent with previous studies that have reported an improved responsiveness of the pancreatic beta cells to glucose when isolated mouse islets were incubated with liraglutide [10]. 
In conclusion, we have demonstrated that liraglutide restores pancreatic beta cell mass due to acute effects on cell kinetics and chronic effects on oxidative and ER stress that are secondary to improvements in glucolipotoxicity. These conclusions were mainly obtained by analysing the changes of gene expression in pancreatic islet cells. To fully understand the effect of liraglutide on pancreatic beta cell mass, further investigations, e.g. assessing the effect of liraglutide on peptide expression and function, as well as its role in neogenesis from the ducts, should be conducted.

Acknowledgements This study was supported by a Grant-in-Aid from the Japan Society for the Promotion of Science (18591008, 21591153 to K. Kaku) and Research Project Grants from Kawasaki Medical School (18-501, 19-502, 20-505 to K. Kaku). We thank L. Bierre Knudsen, Novo Nordisk, for the generous gift of liraglutide and for valuable advice for this study. Abstracts of this report were presented at the 68th annual scientific session of the American Diabetes Association (San Francisco) and the 45th annual meeting of the European Association for the Study of Diabetes (Vienna).

Duality of interest The authors declare that there is no duality of interest associated with this manuscript.

Open Access This article is distributed under the terms of the Creative Commons Attribution Noncommercial License which permits any noncommercial use, distribution, and reproduction in any medium, provided the original author(s) and source are credited.

\section{References}

1. UK Prospective Diabetes Study (UKPDS) Group (1995) Overview of 6 years' therapy of type II diabetes (UKPDS 16). Diabetes 44:1249-1258

2. Bagdade JD, Bierman EL, Porte D Jr (1967) The significance of basal insulin levels in the evaluation of the insulin response to glucose in diabetic and nondiabetic subjects. J Clin Invest 46:1549-1557

3. Butler AE, Janson J, Bonner-Weir S, Ritzel R, Rizza RA, Butler PC (2003) Beta-cell deficit and increased beta-cell apoptosis in humans with type 2 diabetes. Diabetes 52:102-110

4. Buchanan TA, Xiang AH, Peters RK et al (2002) Preservation of pancreatic beta-cell function and prevention of type 2 diabetes by pharmacological treatment of insulin resistance in high-risk Hispanic women. Diabetes 51:2796-2803

5. Ovalle F, Bell DS (2004) Effect of rosiglitazone vs insulin on the pancreatic beta-cell function of subjects with type 2 diabetes. Diab Care 27:2585-2589

6. Pospisilik JA, Martin J, Doty T et al (2003) Dipeptidyl peptidase IV inhibitor treatment stimulates beta-cell survival and islet neogenesis in streptozotocin-induced diabetic rats. Diabetes $52: 741-750$

7. Rolin B, Larsen MO, Gotfredsen CF et al (2002) The long-acting GLP-1 derivative NN2211 ameliorates glycemia and increases beta-cell mass in diabetic mice. Am J Physiol Endocrinol Metab 283:E745-E752

8. Tourrel C, Bailbe D, Lacorne M, Meile MJ, Kergoat M, Portha B (2002) Persistent improvement of type 2 diabetes in the GotoKakizaki rat model by expansion of the beta-cell mass during the prediabetic period with glucagon-like peptide-1 or exendin-4. Diabetes 51:1443-1452

9. Fehmann HC, Habener JF (1992) Insulinotropic hormone glucagon-like peptide-I (7-37) stimulation of proinsulin gene expression and proinsulin biosynthesis in insulinoma beta TC-1 cells. Endocrinology 130:159-166

10. Wang Y, Perfetti R, Greig NH et al (1997) Glucagon-like peptide-1 can reverse the age-related decline in glucose tolerance in rats. J Clin Invest 99:2883-2889

11. D’Alessio DA, Kahn SE, Leusner CR, Ensinck JW (1994) Glucagon-like peptide 1 enhances glucose tolerance both by stimulation of insulin release and by increasing insulinindependent glucose disposal. J Clin Invest 93:2263-2266

12. Mojsov S, Weir GC, Habener JF (1987) Insulinotropin: glucagonlike peptide I (7-37) co-encoded in the glucagon gene is a potent stimulator of insulin release in the perfused rat pancreas. J Clin Invest 79:616-619

13. Kreymann B, Williams G, Ghatei MA, Bloom SR (1987) Glucagon-like peptide-1 7-36: a physiological incretin in man. Lancet 2:1300-1304

14. Orskov C, Holst JJ, Nielsen OV (1988) Effect of truncated glucagon-like peptide-1 [proglucagon-(78-107) amide] on endocrine secretion from pig pancreas, antrum, and nonantral stomach. Endocrinology 123:2009-2013

15. Nauck MA, Wollschlager D, Werner J et al (1996) Effects of subcutaneous glucagon-like peptide 1 (GLP-1 [7-36 amide]) in patients with NIDDM. Diabetologia 39:1546-1553

16. Wettergren A, Schjoldager B, Mortensen PE, Myhre J, Christiansen J, Holst JJ (1993) Truncated GLP-1 (proglucagon 72-107 amide) inhibits gastric and pancreatic function in man. Dig Dis Sci 38:665673

17. Näslund E, Gutniak MK, Skogar S, Rössner S, Hellström PM (1998) GLP-1 increases the period of postprandial satiety and slows gastric emptying in obese humans. Am J Clin Nutr 68:525530

18. Näslund E, Barkeling B, King N et al (1999) Energy intake and appetite are suppressed by glucagon-like-peptide 1 (GLP-1) in obese men. Int J Obes Relat Metab Disord 23:304-311

19. Lee YS, Shin S, Shigihara T et al (2007) Glucagon-like peptide-1 gene therapy in obese diabetic mice results in long-term cure of diabetes by improving insulin sensitivity and reducing hepatic gluconeogenesis. Diabetes 56:1671-1679

20. Xu G, Stoffers DA, Habener JF, Bonner-Weir S (1999) Exendin-4 stimulates both beta-cell replication and neogenesis, resulting in increased beta-cell mass and improved glucose tolerance in diabetic rats. Diabetes 48:2270-2276

21. Friedrichsen BN, Neubauer N, Lee YC et al (2006) Stimulation of pancreatic beta-cell replication by incretins involves transcriptional induction of cyclin D1 via multiple signalling pathways. J Endocrinol 188:481-492

22. Paris M, Tourrel-Cuzin C, Plachot C, Ktorza A (2004) Review: pancreatic beta-cell neogenesis revisited. Exp Diabesity Res $5: 111-121$

23. Li Y, Hansotia T, Yusta B, Ris F, Halban PA, Drucker DJ (2003) Glucagon-like peptide-1 receptor signaling modulates cell apoptosis. J Biol Chem 278:471-478

24. Bregenholt S, Møldrup A, Blume N et al (2005) The longacting glucagon-like peptide-1 analogue, liraglutide, inhibits beta-cell apoptosis in vitro. Biochem Biophys Res Commun 330:577-584

25. Hui H, Nourparvar A, Zhao X, Perfetti R (2003) Glucagon-like peptide-1 inhibits apoptosis of insulin-secreting cells via a cyclic 5 '-adenosine monophosphate-dependent protein kinase A- and a phosphatidylinositol 3-kinase-dependent pathway. Endocrinology 144:1444-1455 
26. Tews D, Lehr S, Hartwig S, Osmers A, Paslack W, Eckel J (2009) Anti-apoptotic action of exendin-4 in INS-1 beta cells: comparative protein pattern analysis of isolated mitochondria. Horm Metab Res 41:294-301

27. Meier JJ, Nauck MA (2004) The potential role of glucagon-like peptide 1 in diabetes. Curr Opin Investig Drugs 5:402-410

28. Bjerre Knudsen L (2004) Glucagon-like peptide I: the basis of a new class of treatment for type 2 diabetes. J Med Chem 47:4128-4134

29. Drucker DJ, Nauck MA (2006) The incretin system: glucagon-like peptide-1 receptor agonists and dipeptidyl peptidase-4 inhibitors in type 2 diabetes. Lancet 368:1696-1705

30. Kitamura T, Kido Y, Nef S, Merenmies J, Parada LF, Accili D (2001) Preserved pancreatic beta-cell development and function in mice lacking the insulin receptor-related receptor. Mol Cell Biol 21:5624-5630

31. Farilla L, Hui H, Bertolotto C et al (2002) Glucagon-like peptide-1 promotes islet cell growth and inhibits apoptosis in Zucker diabetic rats. Endocrinology 143:4397-4408

32. Kanda Y, Shimoda M, Hamamoto S et al (2010) Molecular mechanism by which pioglitazone preserves pancreatic $\beta$ cells in obese diabetic mice: evidence for acute and chronic actions as a PPAR $\gamma$ agonist. Am J Physiol Endocrinol Metab 298:E278-E286

33. Jensen JN, Cameron E, Garay MV et al (2005) Replication of elements of embryonic development in adult mouse pancreatic regeneration. Gastroenterology 128:728-741

34. Miyamoto Y, Maitra A, Ghosh B et al (2003) Notch mediates TGF alpha-induced changes in epithelial differentiation during pancreatic tumorigenesis. Cancer Cell 3:565-576

35. Bar Y, Russ HA, Knoller S et al (2008) HES-1 is involved in adaptation of adult human beta-cells to proliferation in vitro. Diabetes 57:2413-2420
36. Bock T, Pakkenberg B, Buschard K (2003) The endocrine pancreas in non-diabetic rats after short-term and long-term treatment with the long-acting GLP-1 derivative NN2211. APMIS 111:1117-1124

37. Frödin M, Sekine N, Roche E et al (1995) Glucose, other secretagogues, and nerve growth-factor stimulate mitogen-activated protein-kinase in the insulin-secreting beta-cell line, INS-1. J Biol Chem 270:7882-7889

38. Buteau J, Roduit R, Susini S, Prentki M (1999) Glucagon-like peptide-1 promotes DNA synthesis, activates phosphatidylinositol 3-kinase and increases transcription factor pancreatic and duodenal homeobox gene 1 (PDX-1) DNA binding activity in beta (INS-1)-cells. Diabetologia 42:856-864

39. Buteau J, Foisy S, Joly E, Prentki M (2003) Glucagon-like peptide 1 induces beta-cell proliferation via transactivation of the epidermal growth factor receptor. Diabetes 52:124-132

40. Buteau J, Foisy S, Rhodes CJ, Carpenter L, Biden TJ, Prentki M (2001) Protein kinase $C \zeta$ activation mediates glucagon-like peptide-1-induced pancreatic beta-cell proliferation. Diabetes 50:2237-2243

41. Costes S, Broca C, Bertrand G et al (2006) ERK1/2 control phosphorylation and protein level of cAMP-responsive elementbinding protein: a key role in glucose-mediated pancreatic betacell survival. Diabetes 55:2220-2230

42. Hammar E, Parnaud G, Bosco D et al (2004) Extracellular matrix protects pancreatic beta-cells against apoptosis: role of short- and long-term signaling pathways. Diabetes 53:2034-2041

43. Yusta B, Baggio LL, Estall JL et al (2006) GLP-1 receptor activation improves beta cell function and survival following induction of endoplasmic reticulum stress. Cell Metab 4:391406 